Article

\title{
Synthesis of Carbohydrate-Grafted Glycopolymers Using a Catalyst-Free, Perfluoroarylazide-Mediated Fast Staudinger Reaction
}

\author{
William Ndugire, Bin Wu and Mingdi Yan *(D) \\ Department of Chemistry, University of Massachusetts Lowell, 1 University Ave., Lowell, MA 01854, USA; \\ William_Ndugire@student.uml.edu (W.N.); Bin_Wu1@student.uml.edu (B.W.) \\ * Correspondence: mingdi_yan@uml.edu; Tel.: +978-934-3647
}

Received: 5 December 2018; Accepted: 30 December 2018; Published: 3 January 2019

check for updates

\begin{abstract}
Glycopolymers have gained increasing importance in investigating glycan-lectin interactions, as drug delivery vehicles and in modulating interactions with proteins. The synthesis of these glycopolymers is still a challenging and rigorous exercise. In this regard, the highly efficient click reaction, copper (I)-catalyzed alkyne-azide cycloaddition, has been widely applied not only for its efficiency but also for its tolerance of the appended carbohydrate groups. However, a significant drawback of this method is the use of the heavy metal catalyst which is difficult to remove completely, and ultimately toxic to biological systems. In this work, we present the synthesis of carbohydrate-grafted glycopolymers utilizing a mild and catalyst-free perfluorophenyl azide (PFPA)-mediated Staudinger reaction. Using this strategy, mannose (Man) and maltoheptaose (MH) were grafted onto the biodegradable poly(lactic acid) (PLA) by stirring a PFAA-functionalized PLA with a phosphine-derivatized Man or MH in DMSO at room temperature within an hour. The glycopolymers were characterized by ${ }^{1} \mathrm{H}-\mathrm{NMR},{ }^{19} \mathrm{~F}-\mathrm{NMR},{ }^{31} \mathrm{P}-\mathrm{NMR}$ and FTIR.
\end{abstract}

Keywords: Glycopolymer; post-polymerization functionalization; perfluoroaryl azides; Staudinger reaction

\section{Introduction}

Carbohydrates are not only the core of metabolism in many biological systems, but are also integral in many cells as structural [1], communication [2], and recognition [3] elements. Synthetic carbohydrate-functionalized polymers, i.e., glycopolymers, has become an important tool in fundamental glycobiology research, and in biomedical applications such as sensing [4,5], drug delivery [6], and cryopreservation [7,8]. Synthetic glycopolymers can be categorized broadly into two types based on the mode of synthesis: (1) polymerization of carbohydrate-derivatized monomers (such as allyl [9], acrylamide [10] and acrylate [11]), and (2) grafting of carbohydrates onto a polymer backbone [12-17]. The latter technique, typically referred to as post-polymerization modification, allows facile synthesis of the polymer backbone and control over carbohydrate grafting density. To successfully graft carbohydrates onto the polymer, the conjugation reaction must be highly efficient, of high yield, and tolerant of the functional groups on the polymer. The popular 'click' type of reactions, particularly the copper(I)-catalyzed alkyne-azide cycloaddition (CuAAC), meet these requirements and have been applied in the synthesis of glycopolymers by post-polymerization and in glycosylation of surfaces [18-20]. This reaction tolerates a wide variety of carbohydrate side groups. Analytically, it offers the advantage in the form of the distinct chemical shift of the triazole proton in ${ }^{1} \mathrm{H}-\mathrm{NMR}$ that facilitates straightforward characterization [21,22]. However, a drawback of this reaction is the necessity of $\mathrm{Cu}(\mathrm{I})$ catalyst that has proved difficult to be removed completely from the 
products. While at least $2-5 \mathrm{~mol} \%$ of $\mathrm{Cu}(\mathrm{I})$ is required to achieve a respectable reaction rate, even small amounts of residual metal in the final product has been shown to denature proteins and cause oxidative damage to cells $[21,23,24]$. Other click-type reactions that do not require metal catalysts include SPAAC (strain-promoted azide-alkyne cycloaddition), azide-aryne based "benzyne click" reaction, and iEDDA (inverse electron demand Diels-Alder) reaction [25-27], but these have not been applied directly in the synthesis of glycopolymers.

Another click-type reaction is the phosphine-azide Staudinger reaction [28]. The recent improvement by Bertozzi via the introduction of an ester trap [29] rendered this bioorthogonal reaction suitable for in vivo conjugations [30,31] and in oligosaccharide metabolic engineering for cell-surface labelling [29,32]. Despite its versatility, the Staudinger ligation suffers from a slow reaction rate. To overcome this issue, we have recently shown that by using an electron-deficient perfluoroaryl azide (PFPA), the rate of reaction can be increased up to four orders of magnitude to give an iminophosphorane product [33]. The rate enhancement can be attributed to the highly electronegative F atoms lowering the LUMO of PFPA thus accelerating the reactions with dienophiles and nucleophiles [34-37]. In addition, the PFPA-iminophosphorane formed in this reaction was stable and not readily hydrolyzed in vivo, as demonstrated in the metabolic labeling of A549 cells [33].

The fast reaction rate and high yield make this PFPA-Staudinger reaction an excellent candidate for polymerization. In an earlier work, we demonstrated that the reaction of bis-PFPA and a bisphosphene occurred at room temperature in $30 \mathrm{~min}$ to yield poly(iminophosphorane) having molecular weight of over 59,000 and a narrow dispersity of 1.1-1.2 [38]. In this work, we applied this reaction in the post-polymerization synthesis of carbohydrate-grafted glycopolymers. By taking advantage of the fast reaction rate, mild reaction conditions, and high chemoselectivity of the PFPA-Staudinger reaction, we conjugated maltoheptaose and mannose onto poly(lactic acid) (PLA), a biocompatible and biodegradable glycopolymer.

\section{Results and Discussion}

While the availability of pendant functional groups like the hydroxyl on the polymer would be suited for condensation with a carboxyl-modified sugar, this strategy is less desirable as it requires the use of coupling agents that can be difficult to remove like DCC/DMAP [39] or strong acid [40] that would hydrolyze the polymer.

Our design for grafting carbohydrates to PLA was to functionalize PLA with PFPA followed by reaction with a phosphine-derivatized carbohydrate. A PLA-co-PLA-PFPA copolymer is synthesized so that the density of PFPA and the carbohydrate can be varied and controlled. A hydroxy-functionalized polylactide copolymer 4 (Scheme 1A) was synthesized to conjugate PFPA and subsequently graft the carbohydrate. The benzyl-derivatized lactide monomer 1 was synthesized according to Scheme 1B. Ring-opening copolymerization of lactide $\mathbf{1}$ and lactide $\mathbf{2}$ in toluene using stannous octoate as the catalyst gave polylactide copolymer 4 in $74 \%$ yield [5]. The ratio of the two monomers can be varied so as to control the grafting density of carbohydrate on the PLA polymer. In this work, the polymer obtained had a monomer ratio (m:n) of 1:22 for 1 and 2 after copolymerization. Deprotection of the benzyl group on 3 gave the hydroxy-functionalized polylactide copolymer 4 in 63\% yield [5]. The m:n ratio was calculated from the ${ }^{1} \mathrm{H}-\mathrm{NMR}$ spectrum of 4 (Figure $1 \mathrm{~A}$ ) by taking the ratio of the methine protons $(\mathrm{H}-\mathrm{a}$ and $\mathrm{H}-\mathrm{c})$ that overlap at $5.2 \mathrm{ppm}$. The integral value of the $\mathrm{H}-\mathrm{a}$ is equivalent to methylene protons $\mathrm{H}-\mathrm{b} / 2$. Subtraction of this value from the overlapped $(\mathrm{H}-\mathrm{a}+\mathrm{H}-\mathrm{c})$ gives the integration of $\mathrm{H}-\mathrm{c}$ and therefore $\mathrm{H}-\mathrm{a} / \mathrm{H}-\mathrm{c}$ can be calculated. 
(A)<smiles>O=C1OCCOC1COCc1ccccc1</smiles>

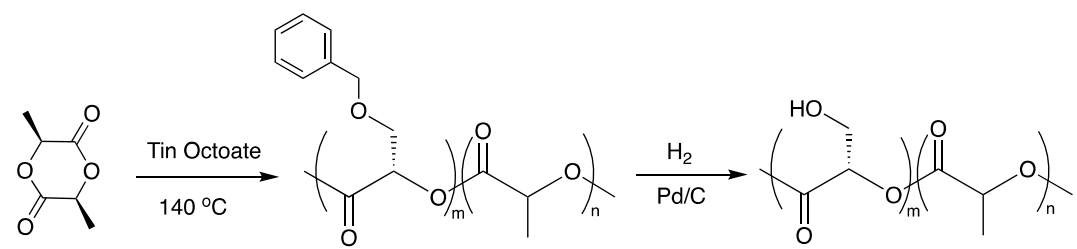
1 2 3

4

(B)

$$
\begin{aligned}
& \overbrace{\mathrm{NH}_{2}}^{\mathrm{O}} \\
& \underset{\mathrm{H}_{2} \mathrm{O}, 25^{\circ} \mathrm{C}, 6 \mathrm{~h}}{\stackrel{\mathrm{NaNO}_{2}, \mathrm{TFA}}{\longrightarrow}}
\end{aligned}
$$<smiles>O=C(O)C(O)COCc1ccccc1</smiles>

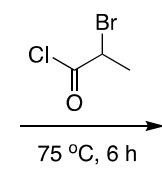

II<smiles>CCC(=O)OC(COCc1ccccc1)C(=O)O</smiles><smiles>O=C(CI)OC(COCc1ccccc1)C(=O)O</smiles><smiles>CCOC(C)=O</smiles><smiles>CC1OC(=O)C(COCc2ccccc2)OC1=O</smiles>

Scheme 1. Synthesis of (A) hydroxy-functionalized polylactide copolymer 4, and (B) lactide monomer 1 .

(A)

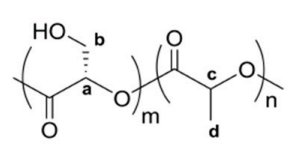

4

(B)
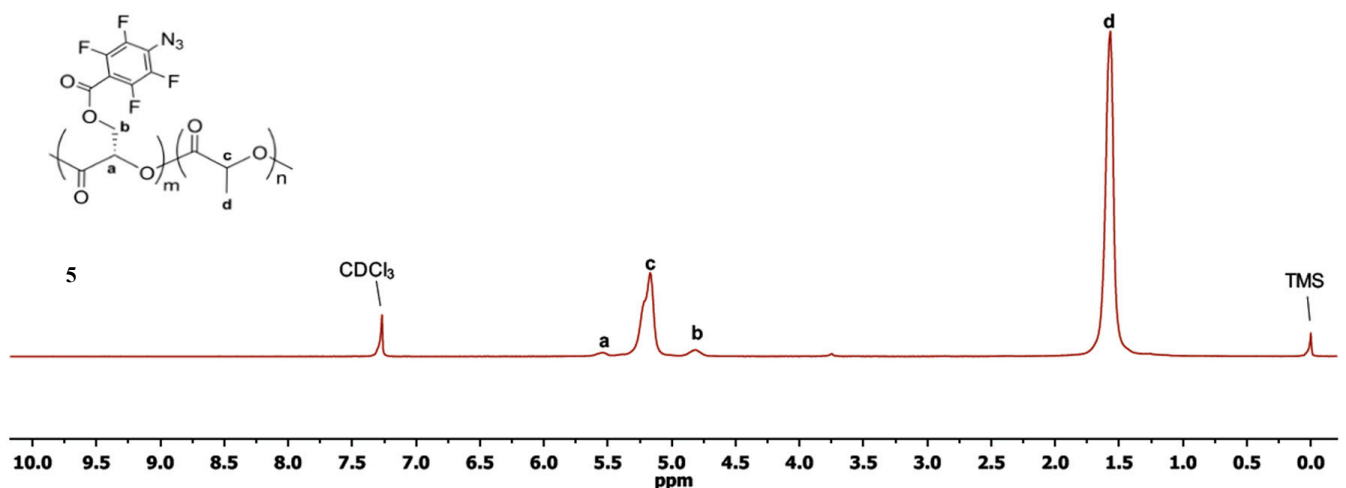

Figure 1. ${ }^{1} \mathrm{H}-\mathrm{NMR}$ spectra of copolymers $4(\mathbf{A})$ and $5(\mathbf{B})$ in $\mathrm{CDCl}_{3}$.

PFPA-functionalized PLA copolymer 5 was prepared by esterification of 4 with carboxy-derivatized PFPA using DCC and a catalytic amount of DMAP giving 5 in $86 \%$ yield (Scheme 2). 
<smiles>CC(C)OC(C)C(=O)OCC(C)C(C)CO</smiles>

4

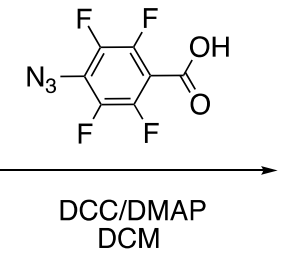

DCM

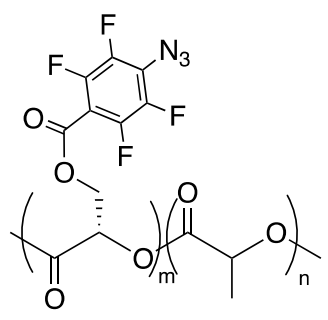

5

Scheme 2. Synthesis of PFPA-PLA copolymer 5.

The ${ }^{1} \mathrm{H}-\mathrm{NMR}$ spectrum of 5 showed a near complete reaction as demonstrated by a marked shift of the methylene proton $\mathrm{H}-\mathrm{b}$ from $4.05 \mathrm{ppm}$ to $4.83 \mathrm{ppm}$ (Figure 1). No degradation of the copolymers to the free lactic acid monomer was observed during the reaction, as evidenced by the absence of peaks at $\sim 1.2 \mathrm{ppm}$ which belongs to the free lactic acid. In addition, the characteristic azide peak at $2133 \mathrm{~cm}^{-1}$ appeared in the Fourier transform-infrared spectroscopy (FTIR) spectrum of copolymer 5 (Figure 2).

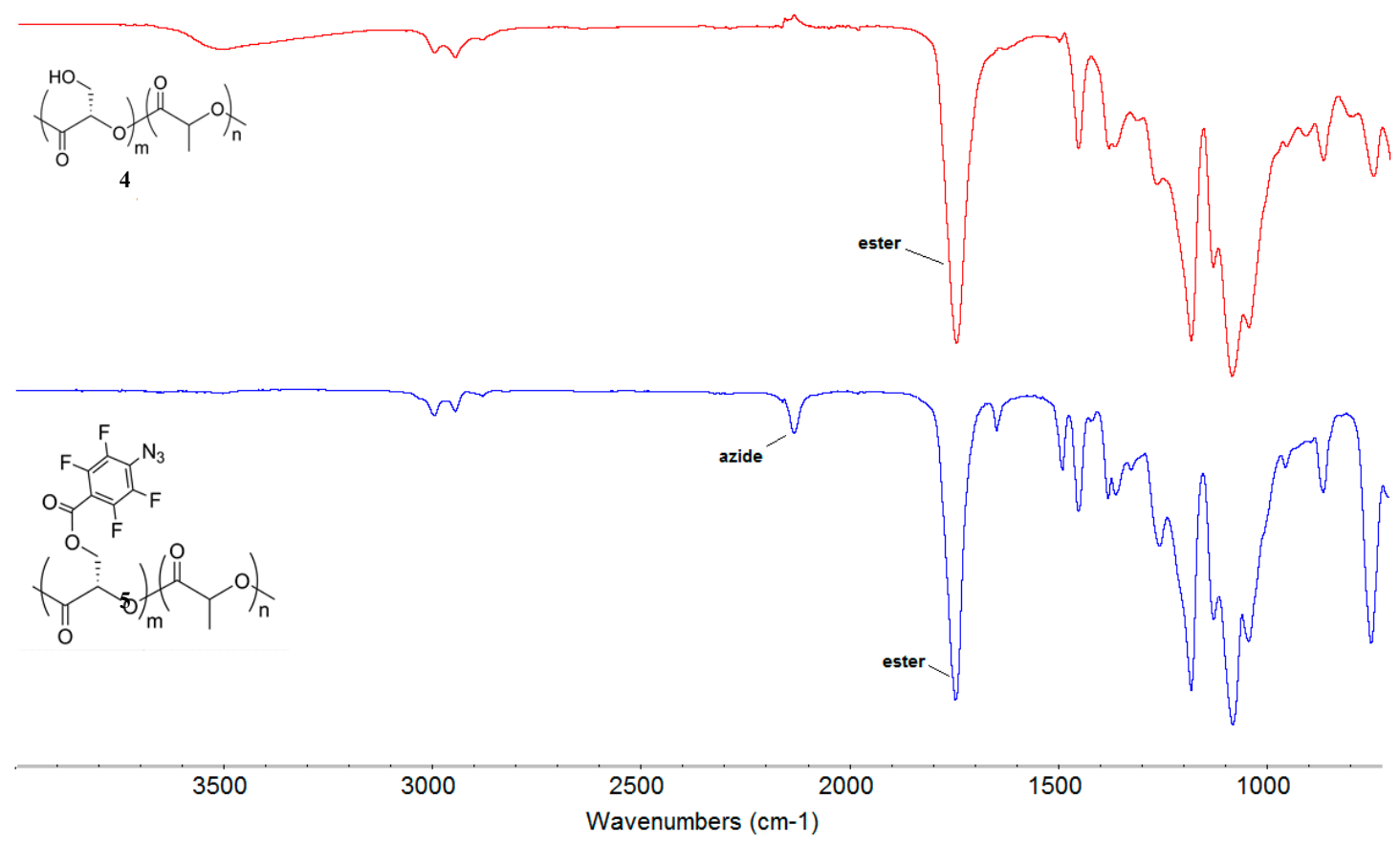

Figure 2. FTIR spectra of PLA copolymers 4 and 5.

The phosphine-derivatized carbohydrates were prepared from an amine-derivatized carbohydrate and the NHS-functionalized phosphine (Scheme 3). A monosaccharide, D-mannose (Man), and an oligosaccharide, D-maltoheptaose $(\mathrm{MH})$, were used as model carbohydrates in this study. The amine-Man 6 was synthesized according to previously reported procedure (see Scheme S2 and detailed procedures in SI) [41]. The amine-MH 7 was synthesized following the procedure in Scheme S1 (see detailed procedures in SI). Reaction of NHS-functionalized triphenylphosphine with excess of 6 or 7 in DMSO at room temperature gave the triphenylphosphine-derivatized Man (8) or MH (9). 


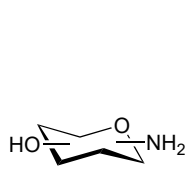

$6 / 7$

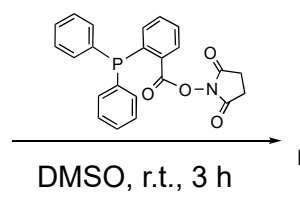

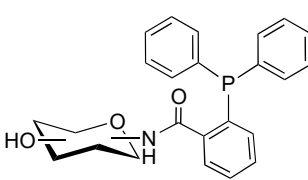

$8 / 9$

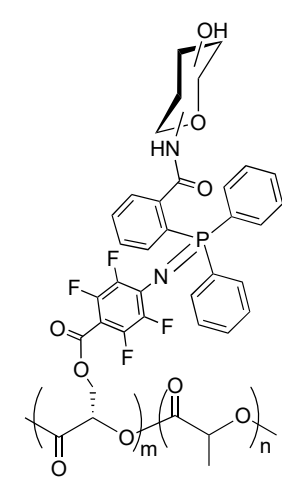

$10 / 11$

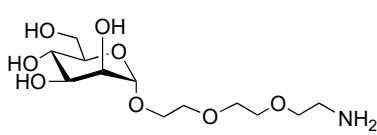

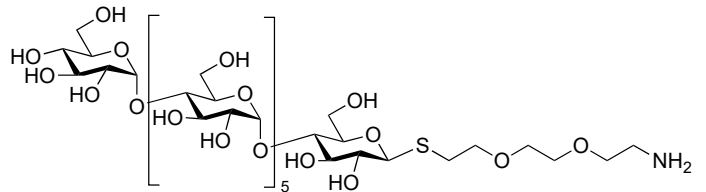

7

Scheme 3. Synthesis of phosphine-derivatized mannose 8 and maltoheptaose $\mathbf{9}$, and subsequent grafting to PFPA-PLA copolymer 5 to yield mannose-polymer 10 and maltoheptaose-polymer 11, respectively.

To prepare Man- or MH-grafted PLA 10 and 11, copolymer 5 was added directly to the reaction mixture of 8 or 9 in DMSO and stirred at room temperature for $1 \mathrm{~h}$. The products were purified by dialysis for $48 \mathrm{~h}$ and dried by lyophilization. After the carbohydrate was grafted, the aromatic and the carbohydrate peaks appeared in the ${ }^{1} \mathrm{H}-\mathrm{NMR}$ spectra of $\mathbf{1 0}$ and $\mathbf{1 1}$ at 7.5-7.7 ppm and 3.0-6.0 ppm, respectively (Figure 3). In the ${ }^{31} \mathrm{P}-\mathrm{NMR}$ spectra of the products (Figure 4), a new peak was observed at 13 ppm after conjugation of the phosphine onto the copolymer. The absence of any peaks higher than 13 ppm confirmed the absence of byproducts resulting from the oxidation of phosphine.

The yield of conjugation was obtained from the ${ }^{1} \mathrm{H}-\mathrm{NMR}$ spectrum by taking the ratio of peak integration of the phenyl protons $(\mathrm{Ph})$ at 7.5-7.7 ppm and the methyl protons $\mathrm{H}-\mathrm{b}$ at $1.48 \mathrm{ppm}$, together with the previously calculated monomer ratio of $m: n=1: 22$ to give the formula:

$$
(\%) \text { coupling yield }=\left(\frac{\frac{P h}{14} \times 22}{\frac{H-b}{3}}\right) \times 100
$$

Using this equation, the yields were calculated to be $25 \%$ and $35 \%$ for the Man-grafted PLA copolymer 10 and MH-grafted PLA copolymer 11, respectively (see Figures S5 and S6 for peak integrations). 


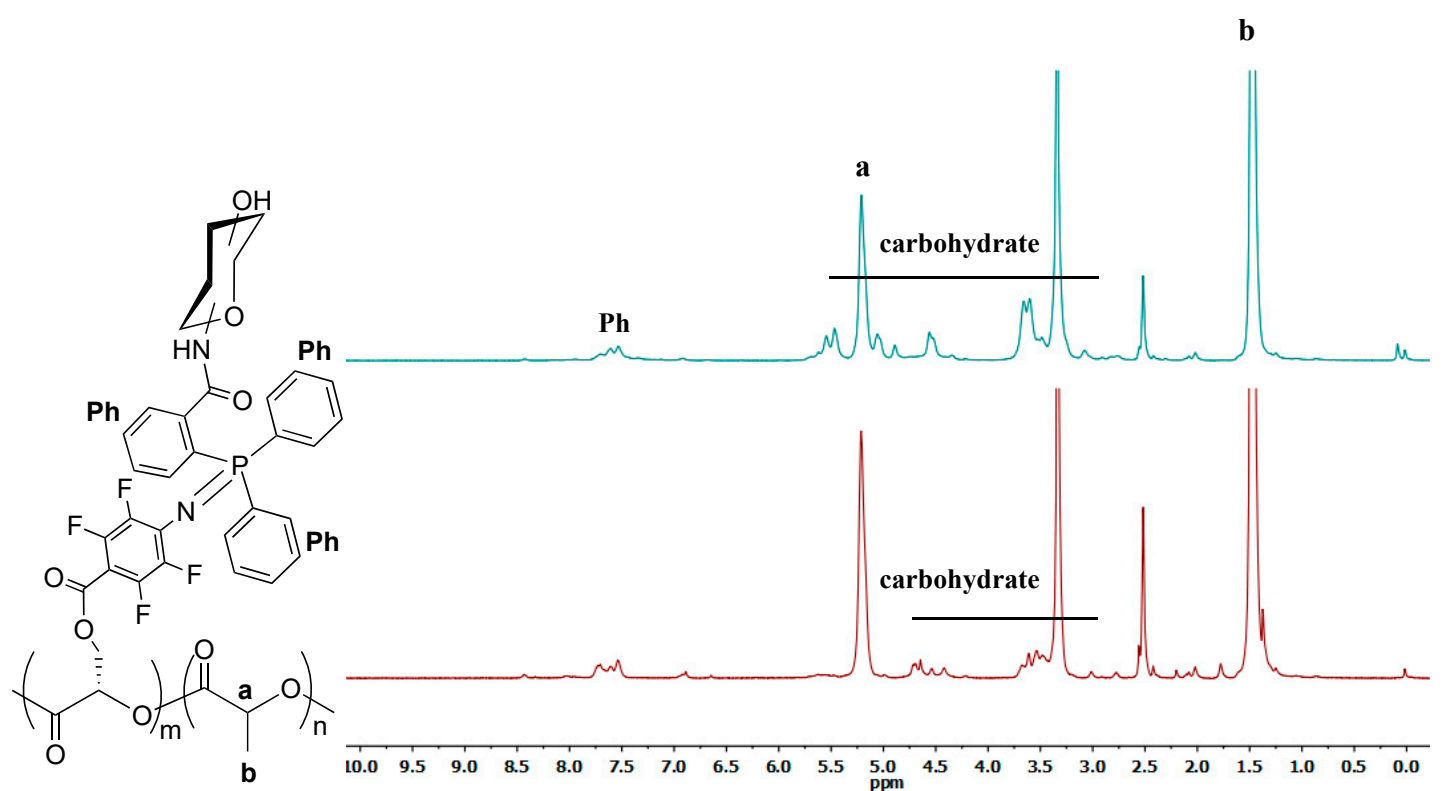

Figure 3. ${ }^{1} \mathrm{H}-\mathrm{NMR}$ spectra of Man- and MH-grafted copolymers 10 (top) and $\mathbf{1 1}$ (bottom) in DMSO-d . $_{6}$

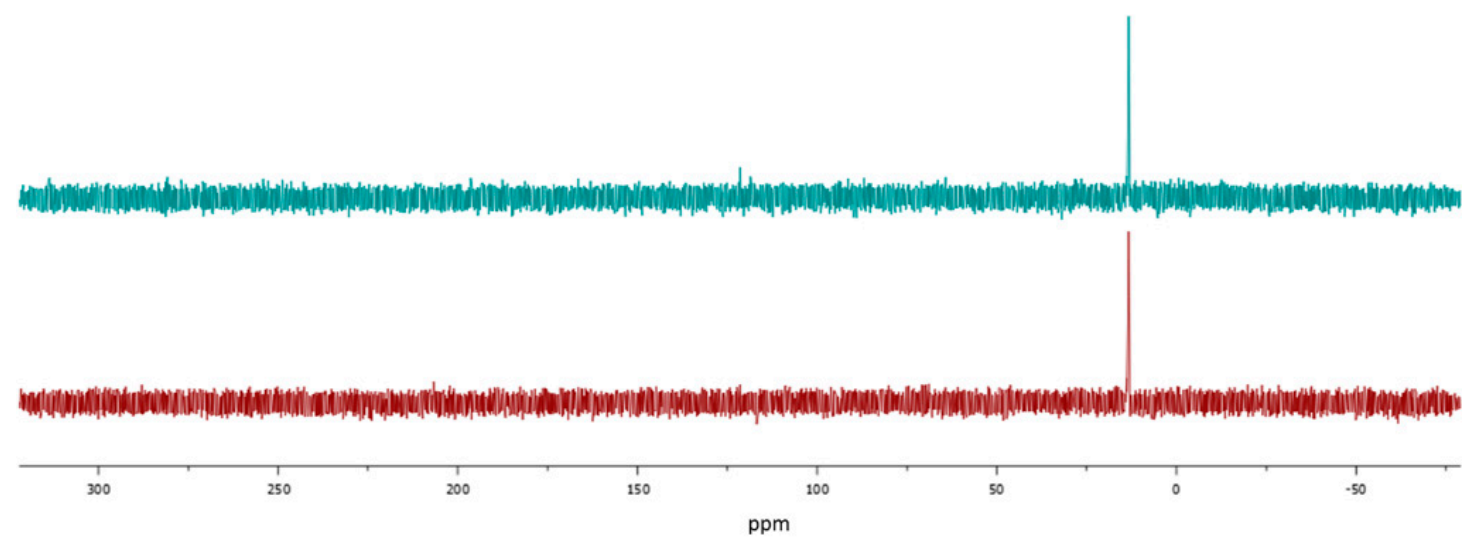

Figure $4 .{ }^{31} \mathrm{P}-\mathrm{NMR}$ spectra of copolymer 10 (top) and $\mathbf{1 1}$ (bottom) in DMSO- $\mathrm{d}_{6}$.

\section{Conclusions}

In this work, we utilized an electron-deficient perfluorophenyl azide-mediated fast Staudinger reaction to efficiently synthesize carbohydrate grafted-polylactide glycopolymers by post-polymerization modification. A polylactide copolymer was synthesized by stannous octoate-catalyzed cationic ring-opening copolymerization, which was subsequently modified with PFPA. Conjugation with a phosphine-derivatized carbohydrate yield mannose- and maltoheptaose-grafted polylactide glycopolymers in $35 \%$ and $25 \%$ yields. These yields are comparable to those obtained by other groups in post-polymerization synthesis of glycopolymers using other techniques [42,43]. The main limiting factor of efficient grafting being steric hindrance between ligands and the polymer backbone restricting access to the reactive sites. In our work, this occurs between carbohydrate-phosphines reaction with the pendant PFPA groups, which is further complicated by the difference in polarity between the PLA and D-mannose/maltoheptaose. However, the grafting reaction is fast, carried out under mild conditions without the use of any catalyst. This metal catalyst-free approach to glycopolymer synthesis is significant as it eliminates the concerns over the potential toxicity of heavy metals, making these glycopolymers attractive for biomedical applications. 


\section{Experimental Procedures}

\subsection{Materials and Instruments}

All chemicals and solvents were purchased from Sigma-Aldrich (St. Louis, MO, USA), TCI America (Portland, Oregon, USA) or Fisher Scientific (Hampton, NH, USA), and were used without further purification unless otherwise noted. Dichloromethane (DCM), dimethylformamide (DMF), ethyl acetate (EtOAc) and dimethyl sulfoxide (DMSO) were purified by distillation over $\mathrm{CaH}_{2}$. Deuterated solvents were acquired from Cambridge Isotope Lab., Inc. (Tewksbury, MA, USA). Amberlite IRC $-120 \mathrm{H}^{+}$resin was activated by washing with $\mathrm{NaOH}$ and $\mathrm{HCl}$, followed by water, ethanol and toluene.

Nuclear magnetic resonance spectroscopy data were collected on either a Bruker $500 \mathrm{MHz}$ spectrometer $\left({ }^{1} \mathrm{H}-\mathrm{NMR}\right)$ or a Bruker $200 \mathrm{MHz}$ spectrometer $\left({ }^{19} \mathrm{~F}\right.$ - and $\left.{ }^{31} \mathrm{P}-\mathrm{NMR}\right)$ (Bruker Corporation, Billerica, MA, USA). FT-IR spectra were recorded on a Nicolet 6700 FT-IR spectrometer (Thermo Fisher Scientific, Waltham, MA, USA).

4-Azido-2,3,5,6-tetrafluorobenzoic acid (PFPA-COOH) was synthesized following our previously developed protocol [44,45]. The detailed synthesis of 1-(2-(2-(2-aminoethoxy)ethoxy)ethoxy- $\alpha$-D-mannopyranoside $\quad(6, \quad$ Scheme S2) [41,46] and 1-(2-(2-(2-aminoethoxy)ethoxy)ethoxy-maltoheptaoside (7, Scheme S1) can be found in the Supporting Information.

\subsection{Synthesis of 3-benzyloxy-2-hydroxypropionic acid (II)}

Synthesized according to literature procedure [47]. To a $200 \mathrm{~mL}$ of $0.7 \mathrm{M}$ aqueous solution of trifluoroacetic acid, H-Ser(benzyl)-OH (I, $10.0 \mathrm{~g}, 52 \mathrm{mmol}$ ) was added, and the mixture was stirred at room temperature until all solids were dissolved. Then, $50 \mathrm{~mL}$ of aqueous $\mathrm{NaNO}_{2}(5.3 \mathrm{~g}, 77 \mathrm{mmol})$ was added dropwise with a syringe pump under Ar protection and the reaction was stirred for another $3 \mathrm{~h}$. After confirming of the consumption of starting material by TLC, $\mathrm{NaCl}$ (10 g) was added and the mixture was extracted with ethyl acetate three times followed by washing with brine and dried over $\mathrm{MgSO}_{4}$. After passing through a flash column using $\mathrm{CH}_{2} \mathrm{Cl}_{2} / \mathrm{MeOH} / \mathrm{AcOH}(v / v / v$ 100:8:1), compound II was obtained (7.2 g, 72\%). ${ }^{31} \mathrm{H}-\mathrm{NMR}\left(500 \mathrm{MHz}, \mathrm{DMSO}-\mathrm{d}_{6}\right) \delta 7.35-7.26(\mathrm{~m}, 5 \mathrm{H}, \mathrm{Ar}-\mathrm{H})$, 4.60 (s, 2H, $\left.\mathrm{PhCH}_{2} \mathrm{O}-\right)$, 4.38 (s, 1H, -OCH$\left.{ }_{2} \mathrm{CH}(\mathrm{COOH}) \mathrm{O}-\right) 3.83$ (d, J = $\left.15 \mathrm{~Hz}, 2 \mathrm{H},-\mathrm{OCH} 2 \mathrm{CH}-\right)$. IR: 3324, 3070,3032 , 2925, 2871, 2645, 2537, 1693, 1495, 1455, 1412, 1379, 1274, 1225, 1202, 1161, 1019, 1001, 973, $926,827,791,732,610,529 \mathrm{~cm}^{-1}$.

\subsection{Synthesis of 3-(benzyloxy)-2-(2-bromopropanoyloxy)propanoic acid (III)}

Synthesized per literature [47]. Compound II (10.0 g, $51 \mathrm{mmol})$ and 2-bromopropionyl chloride $(6.3 \mathrm{~mL}, 61.2 \mathrm{mmol})$ were mixed in a $50-\mathrm{mL}$ round-bottom flask backfilled with Ar. The reaction mixture was heated to $70{ }^{\circ} \mathrm{C}$ and stirred for $6 \mathrm{~h}$. Upon the completion of the reaction, the crude product was heated at $60{ }^{\circ} \mathrm{C}$ under reduced pressure to remove unreacted 2-bromopropionyl chloride and 2-bromopropionyl acid. After cooling to room temperature, the residue was washed with water and extracted with ethyl acetate 3 times. The combined organic phase was washed with brine and dried over $\mathrm{MgSO}_{4}$. Compound III was obtained as a brown oil after further purification by flash column $\mathrm{CH}_{2} \mathrm{Cl}_{2} / \mathrm{MeOH} / \mathrm{AcOH}\left(v / v / v\right.$ 100:2:0.5) (12.6 g, 75\%). ${ }^{1} \mathrm{H}-\mathrm{NMR}\left(500 \mathrm{MHz}, \mathrm{CDCl}_{3}\right): 7.35-7.25$ (m, $5 \mathrm{H}, \mathrm{Ar}-\mathrm{H}), 5.34-5.32\left(\mathrm{~m}, 1 \mathrm{H},-\mathrm{OCH}_{2} \mathrm{CH}(\mathrm{COOH}) \mathrm{O}-\right), 4.62-4.38\left(\mathrm{~m}, 3 \mathrm{H}, \mathrm{PhCH}_{2} \mathrm{O}-\right.$ and $\left.-\mathrm{OCCH}(\mathrm{Br}) \mathrm{CH}_{3}\right)$, 3.97-3.85 (m, 2H, -OCH$\left.{ }_{2} \mathrm{CH}-\right)$, 1.88-1.83 (m, 3H, -CH(Br)CH3). IR: 3442, 3031, 2928, 2871, 1732, 1452, $1362,1211,1155,1097,1070,985,910,738,697,610 \mathrm{~cm}^{-1}$.

\subsection{Synthesis of 3-(benzyloxy)-2-(2-iodopropanoyloxy)propanoic acid (IV)}

Prepare following literature procedures [47]. Compound III (8.0 g, $24 \mathrm{mmol})$ and potassium iodide $(40 \mathrm{~g}, 0.24 \mathrm{~mol})$ were mixed with $100 \mathrm{~mL}$ of anhydrous acetone. The mixture was heated at $60{ }^{\circ} \mathrm{C}$ overnight under Ar. The solid salt was removed by passing through a layer of Celite ${ }^{\circledR}$ and the 
filtrate was concentrated under vacuum. Ethyl acetate was added to the oily residue and the solution was filtered again to remove trace potassium iodide/potassium bromide. The organic phase was washed with $2 \mathrm{M}$ aq. $\mathrm{Na}_{2} \mathrm{~S}_{2} \mathrm{O}_{3}$ for 3 times and dried over $\mathrm{MgSO}_{4}$. After removing the solvent from the filtrate, the product IV was obtained and used directly in the next step without purification (7.5 $\mathrm{g}$, 82\%). ${ }^{1} \mathrm{H}-\mathrm{NMR}\left(500 \mathrm{MHz}, \mathrm{CDCl}_{3}\right): \delta 10.26$ (s, 1H, -COOH), 7.50-7.16 (m, 5H, Ar-H), 5.39 (m, 1H, $\left.-\mathrm{OCH}_{2} \mathrm{CH}(\mathrm{COOH}) \mathrm{O}-\right)$, 4.84-4.41 (m, 3H, $\mathrm{PhCH}_{2} \mathrm{O}-$ and $\left.-\mathrm{OCCH}(\mathrm{Br}) \mathrm{CH}_{3}\right), 3.94(\mathrm{dd}, \mathrm{J}=48.3,10.4 \mathrm{~Hz}$, $\left.2 \mathrm{H},-\mathrm{OCH}_{2} \mathrm{CH}-\right)$, 2.29-1.87 (m, 3H, -CH(I)CH $)$. IR: 2923, 1728, 1496, 1452, 1362, 1197, 1124, 1094, 1043, $1026,977,909,737,697,633,603,582,570,563,554,548,538,529,526 \mathrm{~cm}^{-1}$.

\subsection{Synthesis of 3-(benzyloxymethyl)-6-methyl-1,4-dioxane-2,5-dione (Monomer 1)}

Synthesized as described in literature [7]. A solution of compound IV (10.0 g, $26.8 \mathrm{mmol})$ in dry $\mathrm{CH}_{2} \mathrm{Cl}_{2}(100 \mathrm{~mL})$ was added dropwise to refluxing dry acetone $(1 \mathrm{~L})$ containing DIEA $(8.8 \mathrm{~mL}$, $53.6 \mathrm{mmol}$ ) under Ar. It took $10 \mathrm{~h}$ to finish the addition and the reaction was refluxed for another hour. The solvents were removed under reduced pressure and ether was added to dissolve the crude product. Insoluble ammonium iodide was filtered and the filtrate was concentrated. After purification by flash column chromatography using hexanes/ethyl acetate $(v / v 4: 1)$, the title compound 1 was obtained as a yellow oil $(2.1 \mathrm{~g}, 31 \%)$. The diastereomers were used directly without separation. ${ }^{1} \mathrm{H}-\mathrm{NMR}\left(500 \mathrm{MHz}, \mathrm{CDCl}_{3}\right)$ : (SS) $\delta 7.34-7.26$ (m, 5H, Ar H), 5.24-5.04 (2H; -OCCH(CH$\left.{ }_{2} \mathrm{O}-\right) \mathrm{O}-$ and - $\left.\mathrm{OCCH}\left(\mathrm{CH}_{3}\right) \mathrm{O}-\right)$, 4.61-4.56 (2H; $\left.\mathrm{ArCH}_{2} \mathrm{O}-\right), 3.97$ (2H; -OCH $\left.\mathrm{CH}_{2}\right), 1.63$ (3H; - $\left.\mathrm{CHCH}_{3}\right) . \mathrm{IR}: 2993$ (w, $\left.v_{\mathrm{s}}(\operatorname{aromatic} \mathrm{C}-\mathrm{H})\right), 2942\left(\mathrm{w}, \mathrm{v}_{\mathrm{as}}\left(-\mathrm{CH}_{2}-\right.\right.$ and $\left.\left.-\mathrm{CH}_{3}\right)\right), 2872\left(\mathrm{w}, \mathrm{v}_{\mathrm{s}}\left(-\mathrm{CH}_{2}\right.\right.$ - and aliphatic $\left.\left.-\mathrm{CH}-\right)\right), 1748$ (vs, $v_{\mathrm{s}}($ ester $\left.\mathrm{C}=\mathrm{O})\right), 1453\left(\mathrm{~m}, \delta_{\mathrm{s}}\left(-\mathrm{CH}_{2}-\right)\right), 1365(\mathrm{w}), 1268(\mathrm{w}), 1182(\mathrm{~s}), 1084(\mathrm{vs}), 1046(\mathrm{~m}), 865(\mathrm{w}), 739(\mathrm{~m}$, $\omega($ aromatic C-H $)), 698(\mathrm{~m}, \tau($ aromatic ring $)) \mathrm{cm}^{-1}$.

\subsection{Synthesis of PLA copolymer 3}

Monomer 1 (1.0 g, $4.0 \mathrm{mmol})$, recrystallized L-lactide $(2,1.0 \mathrm{~g}, 6.9 \mathrm{mmol})$ and $\mathrm{Sn}(\mathrm{Oct})_{2}(10 \mathrm{mg}$ in $1 \mathrm{~mL}$ anhydrous toluene) were added into a 5-mL round-bottom flask. The mixture was heated to $70{ }^{\circ} \mathrm{C}$ under vacuum for $1 \mathrm{~h}$. Ar was filled in the flask and the temperature was increased to $140{ }^{\circ} \mathrm{C}$. The mixture was stirred until the stir bar stopped moving. After cooling to room temperature, the solid was dissolved in $\mathrm{CH}_{2} \mathrm{Cl}_{2}$ and hexanes was added. The precipitate was re-dissolved in $\mathrm{CH}_{2} \mathrm{Cl}_{2}$, and this dissolution/precipitation was repeated three times, and the precipitate was finally dried under vacuum to give copolymer $1 \mathrm{c}$ as a dark brown solid $(1.48 \mathrm{~g}, 74 \%)$. ${ }^{1} \mathrm{H}-\mathrm{NMR}\left(500 \mathrm{MHz}, \mathrm{CDCl}_{3}\right) \delta$ $5.20\left(-\mathrm{OCH}_{2} \mathrm{CH}(\mathrm{COOH}) \mathrm{O}-\right.$ and $\left.-\mathrm{OCH}\left(\mathrm{CH}_{3}\right) \mathrm{CO}-\right), 4.59\left(\mathrm{PhCH}_{2} \mathrm{O}-\right), 3.90\left(-\mathrm{OCH}_{2} \mathrm{CH}-\right), 1.56\left(-\mathrm{CHCH}_{3}\right)$. IR (ATR) 2942, 1747, 1497, 1452, 1365, 1192, 1084, 1046, 865, 739, $698 \mathrm{~cm}^{-1}$.

\subsection{Synthesis of PLA copolymer 4}

Following literature synthesis [47]. Copolymer $3(1.0 \mathrm{~g})$ was dissolved in $50 \mathrm{~mL}$ ethyl acetate/methanol (3:1), and catalytic amount of Pd/C was added. The mixture was purged with Ar for $20 \mathrm{~min}$ and filled with $\mathrm{H}_{2}$ under vigorous stirring. After $12 \mathrm{~h}$, the solution was passed through a pile of Celite to remove $\mathrm{Pd} / \mathrm{C}$ and the filtrate was dried under vacuum to give copolymer 4 as a light brown solid (630 mg, 63\%). ${ }^{1} \mathrm{H}-\mathrm{NMR}\left(500 \mathrm{MHz}, \mathrm{CDCl}_{3}\right): \delta 5.0-5.5\left(-\mathrm{OCH}\left(\mathrm{CH}_{2} \mathrm{OH}\right) \mathrm{CO}-\right.$ and $\left.-\mathrm{OCH}\left(\mathrm{CH}_{3}\right) \mathrm{CO}-\right)$, 3.78 (HOCH$\left.{ }_{2} \mathrm{CH}-\right), 1.49$ (- $\left.\mathrm{CHCH}_{3}\right)$. IR (ATR): 3500 (br, w), 2995 (m), 2945 (m), 1744 (s), 1452 (m), 1380 (w), 1182 (s), 1129 (s), $1084(\mathrm{~s}), 864(\mathrm{~m}), 743(\mathrm{~m}) \mathrm{cm}^{-1}$.

\subsection{Synthesis of PFPA-grafted PLA copolymer 5}

Copolymer $4(100 \mathrm{mg})$ and PFPA-COOH $(20 \mathrm{mg}, 0.09 \mathrm{mmol})$ were added together with DCC (41 mg, $0.2 \mathrm{mmol}$ ) and DMAP (2.4 mg, $0.02 \mathrm{mmol}$ ) to $10 \mathrm{~mL}$ anhydrous dichloromethane under Ar, and the mixture was stirred at room temperature overnight. The solution was then concentrated to $3 \mathrm{~mL}$ and was poured into $50 \mathrm{~mL}$ of hexane/methanol $(v / v$ 9:1) to precipitate the crude product. The yellow precipitate was dissolved in dichloromethane and was precipitated in hexane/methanol. This dissolution/ precipitation was repeated for a total of 3 times. Finally, the precipitate was 
dried under vacuum to give PFPA-grafted PLA copolymer 5 as a bright yellow solid (104 mg,

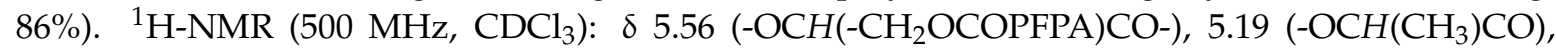
$4.83\left(-\mathrm{OCH}_{2}\right.$ (OCOPFPA)CH-), $1.59\left(-\mathrm{CHCH}_{3}\right) .{ }^{19} \mathrm{~F}-\mathrm{NMR}\left(188 \mathrm{MHz}, \mathrm{CDCl}_{3}\right): \delta-137.5$ (doublet), -149.62 (singlet). FTIR (ATR): 2995 (m), 2945 (m), 2133 (m), 1747 (s), 1648 (w), 1563 (m), 1490 (s), 1381 (m), $1363(\mathrm{~m}), 1258(\mathrm{~s}), 1182(\mathrm{~s}), 1128(\mathrm{~s}), 1082(\mathrm{~s}), 1044(\mathrm{~s}), 957(\mathrm{w}), 865(\mathrm{~m}), 751(\mathrm{~s}), 667(\mathrm{~m}) \mathrm{cm}^{-1}$.

\subsection{Synthesis of Man- or MH-grafted PLA glycopolymers $\mathbf{1 0}$ or $\mathbf{1 1}$}

General Procedures

The mole ratio of $N$-succinimidyl 2-(diphenylphosphanyl)benzoate:amine-carbohydrate: PFPA in polymer $\mathbf{1 0}$ or $\mathbf{1 1}$ was set as 4:6:1. N-Succinimidyl 2-(diphenylphosphanyl) benzoate and amine-Man 6 or amine-MH 7 were added to $5 \mathrm{~mL}$ anhydrous DMSO, and the solution was stirred for $3 \mathrm{~h}$. Then, the mixture was added to a DMSO solution containing copolymer 5 . Afterwards, the mixture was stirred for another hour. The mixture was transferred into a dialysis tube (molecule cutoff: 3500 ) and dialyzed in water for 2 days. Finally, the product was obtained after lyophilization.

Polymer 10: yellow powder (yield: 92\%). ${ }^{1} \mathrm{H}-\mathrm{NMR}\left(500 \mathrm{MHz}, \mathrm{DMSO}-\mathrm{d}_{6}\right): \delta 7.70-7.20(\mathrm{Ar}-\mathrm{H})$, 5.21 (-OCH $\left.\left(\mathrm{CH}_{3}\right) \mathrm{CO}-\right)$, 5.80-3.00 (carbohydrate), 1.48 (- $\left.\mathrm{CHCH}_{3}\right)$; IR (ATR): 3362, 2945, 1747, 1651, 1489 , $1451,1381,1515,1184,1082,1043,865,749,695 \mathrm{~cm}^{-1}$.

Polymer 11: a white powder (yield: 94\%). ${ }^{1} \mathrm{H}-\mathrm{NMR}\left(500 \mathrm{MHz}, \mathrm{DMSO}-\mathrm{d}_{6}\right): 7.75-7.40(\mathrm{Ar}-\mathrm{H}), 5.21$ (-OCH $\left.\left(\mathrm{CH}_{3}\right) \mathrm{CO}-\right), 4.90-3.00$ (carbohydrate), 1.48 (- $\left.\mathrm{CHCH}_{3}\right)$; IR (ATR): 3371, 2945, 1748, 1651, 1503, $1452,1381,1133,1084,865,752,695 \mathrm{~cm}^{-1}$.

Supplementary Materials: Supporting information including detailed synthetic protocols, ${ }^{1} \mathrm{H},{ }^{19} \mathrm{~F}$ and ${ }^{31} \mathrm{P}$ NMR and IR spectra are available online.

Author Contributions: The authors contributed as follows M.Y., B.W. and W.N. in conceptualization, visualization and methodology and synthesis, W.N. and M.Y. in writing-original draft preparation, M.Y., B.W. and W.N. in writing - review and editing; supervision, project administration, and funding acquisition, M.Y.

Funding: This study was supported in part by the National Institute of Health (R15GM128164) and National Science Foundation (CHE-1808671).

Acknowledgments: The authors thank Xuan Chen for his help in the synthesis.

Conflicts of Interest: The authors declare no conflict of interest.

\section{References}

1. Caroff, M.; Karibian, D. Structure of bacterial lipopolysaccharides. Carbohydr. Res. 2003, 338, $2431-2447$. [CrossRef] [PubMed]

2. Ramon, M.; Rolland, F.; Sheen, J. Sugar sensing and signaling. Arabidopsis Book 2008, 6, e0117. [CrossRef] [PubMed]

3. Brandley Brian, K.; Schnaar Ronald, L. Cell—Surface Carbohydrates in Cell Recognition and Response. J. Leukocyte Biol. 1986, 40, 97-111. [CrossRef]

4. Jin, Y.; Wong, K.H.; Granville, A.M. Enhancement of Localized Surface Plasmon Resonance polymer based biosensor chips using well-defined glycopolymers for lectin detection. J. Colloid Interface Sci. 2016, 462, 19-28. [CrossRef] [PubMed]

5. Chen, X.; Wu, B.; Jayawardana, K.W.; Hao, N.; Jayawardena, H.S.N.; Langer, R.; Jaklenec, A.; Yan, M. Magnetic Multivalent Trehalose Glycopolymer Nanoparticles for the Detection of Mycobacteria. Adv. Healthc. Mater 2016, 5, 2007-2012. [CrossRef] [PubMed]

6. Zhou, W.-J.; Kurth, M.J.; Hsieh, Y.-L.; Krochta, J.M. Synthesis and thermal properties of a novel lactose-containing poly(N-isopropylacrylamide-co-acrylamidolactamine) hydrogel. J. Polym. Sci. A Polym. Chem. 2000, 37, 1393-1402. [CrossRef]

7. Newman, Y.M.; Ring, S.G.; Colaco, C. The Role of Trehalose and Other Carbohydrates in Biopreservation. Biotechnol. Genet. Eng. Rev 1993, 11, 263-294. [CrossRef] [PubMed] 
8. Beattie, G.M.; Crowe, J.H.; Lopez, A.D.; Cirulli, V.; Ricordi, C.; Hayek, A. Trehalose: A Cryoprotectant That Enhances Recovery and Preserves Function of Human Pancreatic Islets After Long-Term Storage. Diabetes 1997, 46, 519. [CrossRef]

9. Roy, R.; Tropper, F. Syntheses of copolymer antigens containing 2-acetamido-2-deoxy- $\alpha$ or $\beta$-d-glucopyranosides. Glycoconjugate J. 1988, 5, 203-206. [CrossRef]

10. Cao, S.; Roy, R. Synthesis of glycopolymers containing GM3-saccharide. Tetrahedron Lett. 1996, 37, $3421-3424$. [CrossRef]

11. Desport, J.; Moreno, M.; Barandiaran, M. Fructose-Based Acrylic Copolymers by Emulsion Polymerization. Polymers 2018, 10, 488. [CrossRef]

12. Spain, S.G.; Gibson, M.I.; Cameron, N.R. Recent advances in the synthesis of well-defined glycopolymers. J. Polym. Sci. A Polym. Chem. 2007, 45, 2059-2072. [CrossRef]

13. Varma, A.J.; Kennedy, J.F.; Galgali, P. Synthetic polymers functionalized by carbohydrates: A review. Carbohydr. Polym. 2004, 56, 429-445. [CrossRef]

14. Wang, Q.; Dordick, J.S.; Linhardt, R.J. Synthesis and Application of Carbohydrate-Containing Polymers. Chem. Mater. 2002, 14, 3232-3244. [CrossRef]

15. Yang, L.; Sun, H.; Liu, Y.; Hou, W.; Yang, Y.; Cai, R.; Cui, C.; Zhang, P.; Pan, X.; Li, X.; et al. Self-Assembled Aptamer-Grafted Hyperbranched Polymer Nanocarrier for Targeted and Photoresponsive Drug Delivery. Angew. Chem. Int. Ed. 2018, 57, 17048-17052. [CrossRef] [PubMed]

16. Tang, H.; Tsarevsky, N.V. Preparation and functionalization of linear and reductively degradable highly branched cyanoacrylate-based polymers. J. Polym. Sci. A Polym. Chem. 2016, 54, 3683-3693. [CrossRef]

17. Ding, J.; Xiao, C.; Li, Y.; Cheng, Y.; Wang, N.; He, C.; Zhuang, X.; Zhu, X.; Chen, X. Efficacious hepatoma-targeted nanomedicine self-assembled from galactopeptide and doxorubicin driven by two-stage physical interactions. J. Control. Release 2013, 169, 193-203. [CrossRef] [PubMed]

18. Dondoni, A. Triazole: The Keystone in Glycosylated Molecular Architectures Constructed by a Click Reaction. A. Chem. Asian J. 2007, 2, 700-708. [CrossRef]

19. Pérez-Balderas, F.; Ortega-Muñoz, M.; Morales-Sanfrutos, J.; Hernández-Mateo, F.; Calvo-Flores, F.G.; Calvo-Asín, J.A.; Isac-García, J.; Santoyo-González, F. Multivalent Neoglycoconjugates by Regiospecific Cycloaddition of Alkynes and Azides Using Organic-Soluble Copper Catalysts. Org. Lett. 2003, 5, 1951-1954. [CrossRef] [PubMed]

20. Fazio, F.; Bryan, M.C.; Blixt, O.; Paulson, J.C.; Wong, C.-H. Synthesis of Sugar Arrays in Microtiter Plate. J. Am. Chem. Soc. 2002, 124, 14397-14402. [CrossRef]

21. Aragão-Leoneti, V.; Campo, V.L.; Gomes, A.S.; Field, R.A.; Carvalho, I. Application of copper(I)-catalysed azide/alkyne cycloaddition (CuAAC) 'click chemistry' in carbohydrate drug and neoglycopolymer synthesis. Tetrahedron 2010, 66, 9475-9492. [CrossRef]

22. Slavin, S.; Burns, J.; Haddleton, D.M.; Becer, C.R. Synthesis of glycopolymers via click reactions. Eur. Polym. J. 2011, 47, 435-446. [CrossRef]

23. Baskin, J.M.; Prescher, J.A.; Laughlin, S.T.; Agard, N.J.; Chang, P.V.; Miller, I.A.; Lo, A.; Codelli, J.A.; Bertozzi, C.R. Copper-free click chemistry for dynamic in vivo imaging. Proc. Natl. Acad. Sci. USA 2007, 104, 16793-16797. [CrossRef] [PubMed]

24. Wu, P.; Feldman, A.K.; Nugent, A.K.; Hawker, C.J.; Scheel, A.; Voit, B.; Pyun, J.; Fréchet, J.M.J.; Sharpless, K.B.; Fokin, V.V. Efficiency and Fidelity in a Click-Chemistry Route to Triazole Dendrimers by the Copper(I)-Catalyzed Ligation of Azides and Alkynes. Angew. Chem. Int. Ed. 2004, 43, 3928-3932. [CrossRef]

25. Becer, C.R.; Hoogenboom, R.; Schubert, U.S. Click Chemistry beyond Metal-Catalyzed Cycloaddition. Angew. Chem. Int. Ed. 2009, 48, 4900-4908. [CrossRef]

26. Chang, P.V.; Prescher, J.A.; Sletten, E.M.; Baskin, J.M.; Miller, I.A.; Agard, N.J.; Lo, A.; Bertozzi, C.R. Copper-free click chemistry in living animals. Proc. Natl. Acad. Sci. USA 2010, 107, 1821-1826. [CrossRef]

27. Campbell-Verduyn, L.; Elsinga, P.H.; Mirfeizi, L.; Dierckx, R.A.; Feringa, B.L. Copper-free 'click': 1,3-dipolar cycloaddition of azides and arynes. Org. Biomol. Chem. 2008, 6, 3461-3463. [CrossRef]

28. Staudinger, H.; Meyer, J. Über neue organische Phosphorverbindungen III. Phosphinmethylenderivate und Phosphinimine. Helv. Chim. Acta 1919, 2, 635-646. [CrossRef]

29. Saxon, E.; Bertozzi, C.R. Cell Surface Engineering by a Modified Staudinger Reaction. Science 2000, $287,2007$. [CrossRef] 
30. Köhn, M.; Breinbauer, R. The Staudinger Ligation-A Gift to Chemical Biology. Angew. Chem. Int. Ed. 2004, 43, 3106-3116. [CrossRef]

31. Lin, F.L.; Hoyt, H.M.; van Halbeek, H.; Bergman, R.G.; Bertozzi, C.R. Mechanistic Investigation of the Staudinger Ligation. J. Am. Chem. Soc. 2005, 127, 2686-2695. [CrossRef] [PubMed]

32. Prescher, J.A.; Dube, D.H.; Bertozzi, C.R. Chemical remodelling of cell surfaces in living animals. Nature 2004, 430, 873-877. [CrossRef] [PubMed]

33. Sundhoro, M.; Jeon, S.; Park, J.; Ramström, O.; Yan, M. Perfluoroaryl Azide Staudinger Reaction: A Fast and Bioorthogonal Reaction. Angew. Chem. 2017, 129, 12285-12289. [CrossRef]

34. Xie, S.; Ramström, O.; Yan, M. N,N-Diethylurea-Catalyzed Amidation between Electron-Deficient Aryl Azides and Phenylacetaldehydes. Org. Lett. 2015, 17, 636-639. [CrossRef] [PubMed]

35. Xie, S.; Zhang, Y.; Ramström, O.; Yan, M. Base-catalyzed synthesis of aryl amides from aryl azides and aldehydes. Chem. Sci. 2016, 7, 713-718. [CrossRef] [PubMed]

36. Xie, S.; Lopez, S.A.; Ramström, O.; Yan, M.; Houk, K.N. 1,3-Dipolar Cycloaddition Reactivities of Perfluorinated Aryl Azides with Enamines and Strained Dipolarophiles. J. Am. Chem. Soc. 2015, 137, 2958-2966. [CrossRef] [PubMed]

37. Xie, S.; Fukumoto, R.; Ramström, O.; Yan, M. Anilide Formation from Thioacids and Perfluoroaryl Azides. J. Org. Chem. 2015, 80, 4392-4397. [CrossRef]

38. Sundhoro, M.; Park, J.; Wu, B.; Yan, M. Synthesis of Polyphosphazenes by a Fast Perfluoroaryl Azide-Mediated Staudinger Reaction. Macromolecules 2018, 51, 4532-4540. [CrossRef]

39. Duchateau, J.; Lutsen, L.; Guedens, W.; Cleij, T.J.; Vanderzande, D. Versatile post-polymerization functionalization of poly(p-phenylene vinylene) copolymers containing carboxylic acid substituents: Development of a universal method towards functional conjugated copolymers. Polym. Chem. 2010, 1, 1313-1322. [CrossRef]

40. Ting, S.R.S.; Chen, G.; Stenzel, M.H. Synthesis of glycopolymers and their multivalent recognitions with lectins. Polym. Chem. 2010, 1, 1392-1412. [CrossRef]

41. Kong, N.; Shimpi, M.R.; Park, J.H.; Ramström, O.; Yan, M. Carbohydrate conjugation through microwave-assisted functionalization of single-walled carbon nanotubes using perfluorophenyl azides. Carbohydr. Res. 2015, 405, 33-38. [CrossRef] [PubMed]

42. Peng, K.-Y.; Hua, M.-Y.; Lee, R.-S. Amphiphilic polyesters bearing pendant sugar moieties: Synthesis, characterization, and cellular uptake. Carbohydr. Polym. 2014, 99, 710-719. [CrossRef] [PubMed]

43. Disney, M.D.; Zheng, J.; Swager, T.M.; Seeberger, P.H. Detection of Bacteria with Carbohydrate-Functionalized Fluorescent Polymers. J. Am. Chem. Soc. 2004, 126, 13343-13346. [CrossRef]

44. Liu, L.; Yan, M. A General Approach to the Covalent Immobilization of Single Polymers. Angew. Chem. 2006, 118, 6353-6356. [CrossRef]

45. Wang, X.; Ramström, O.; Yan, M. Dynamic light scattering as an efficient tool to study glyconanoparticle-lectin interactions. Analyst 2011, 136, 4174-4178. [CrossRef] [PubMed]

46. Deng, L.; Norberg, O.; Uppalapati, S.; Yan, M.; Ramström, O. Stereoselective synthesis of light-activatable perfluorophenylazide-conjugated carbohydrates for glycoarray fabrication and evaluation of structural effects on protein binding by SPR imaging. Org. Biomol. Chem. 2011, 9, 3188-3198. [CrossRef] [PubMed]

47. Gerhardt, W.W.; Noga, D.E.; Hardcastle, K.I.; García, A.J.; Collard, D.M.; Weck, M. Functional Lactide Monomers: Methodology and Polymerization. Biomacromolecules 2006, 7, 1735-1742. [CrossRef]

Sample Availability: Samples of the compounds are not currently available from the authors. 